091

Received: July 8, 2009

Accepted: December 4, 2009

\title{
SUSTAINABILITY SUGGESTIONS FOR GOAT HUSBANDRY IN ISPARTA
}

\author{
Duygu İnce, Hayati Köknaroğlu, M.Turan Toker \\ Süleyman Demirel University, Faculty of Agriculture, Department of Animal Science, Isparta, Turkey \\ hayati@ziraat.edu.tr
}

\begin{abstract}
There are approximately 6.3 million head of goats in Turkey and $90.5 \%$ of this population is the Hair goat. The regions in which goat husbandry is intensively practiced are Mediterranean, Aegean and Southeastern Anatolia. There are 168000 heads of goat in Isparta and nearly all of this population is the Hair goat. Ministry of Environment and Forestry is aiming to decrease the goat population to one million and since the ministry has taken some actions, goat producers grazing their goats near forests are under threat. This situation puts goat producers both sociologically and economically under undesired conditions. Isparta province is rich of shrubs that are consumed only by goats. Goats convert shrubs that do not need any resource input for maintenance into animal products and thus help to establish economical, ecological and sustainable animal agriculture in terms of energy use. Sustainability in animal agriculture is very important and is the driving force in animal agriculture. In this paper sustainability in terms of energy use, economics and ecology is considered. It is suggested goat producers breed their Hair goats with higher producing Saanen goats to compensate their loss due to decrease in their goat numbers, and establish organizations to sell their products at a higher price. However some Hair goats which are disease resistant, adapted to malnutrition and well adapted to Isparta conditions, should be kept as an indigenous gene source and be given a chance to pass their genes to the next generation. If some structural measures are not taken, then goat husbandry may lose its sustainability and be lost.
\end{abstract}

Key words: Hair goat; Isparta; sustainability

\section{ПРЕДЛОЗИ ЗА ОДРЖЛИВО ОДГЛЕДУВАЊЕ НА КОЗИТЕ ВО ИСПАРТА}

Во Турција се одгледуваат околу 6,3 милиони грла кози и 90,5\% од оваа популација отпаѓаат на козите од расата ангора. Регионите во кои одгледувањето на кози интензивно се практикува се Медитеранот, Егејот и југоисточната Анадолија. Во Испарта има 168000 грла кози и речиси целокупната популација отпаѓa на ангорската коза. Министерството за животна средина и шумарство има за цел популацијата на козите да ја намали на еден милион откако Министерството презеде одделни чекори, одгледувачите на кози ги напасуваат своите кози во близина на шумите со што ги загрозуваат. Оваа ситуација ги става одгледувачите на кози и од социолошки и од економски аспект во неповолни услови. Провинцијата Испарта е богата со грмушки кои ги консумираат исклучиво козите. Козите ги претвораат грмушките во животински продукти и така овозможуваат создавање рентабилно, еколошко и одржливо сточарско производство во смисла на искористување на енергијата. Одржливото сточарско производство е многу важно и претставува движечка сила во земјоделството. Овој труд претставува осврт на одржливоста на одгледувањето на козите во смисла на енергетска примена, економија и екологија. Се предлага одгледувачите на кози да ги парат ангорските кози со попродуктивните сански кози, за да ја компензираат загубата поврзана со намалувањето на бројот на козите, и да формираат здруженија за продажба на своите производи за да достигнат повисоки цени. Сепак, определен број ангорските кози, кои се отпорни на болести и приспособени на потхранетост и на условите кои владеат во Испарта, треба да се зачува како автохтон генетски ресурс и да се овозможи пренесување на нивните гени на следните генерации. Доколку не се преземат некои структурни мерки, одгледувањето на козите може да ја загуби својата одржливост.

Клучни зборови: ангорска коза; Испарта; одржливост

\section{INTRODUCTION}

Goat husbandry is an important branch of animal production in Turkey considering its eco- nomic and sociologic outcomes. With the products provided, goat husbandry helps people in rural areas make living. Even though its importance is unnoticed, goat industry is a growing and impor- 
tant one. Small ruminant producing countries determine their production strategy depending on their traditional structure and competitiveness. For example, even though Australia decreased its sheep population it increased its goat population $400 \%$ and put its effort in goat production. Another country, New Zealand also increased its goat numbers $554 \%$. Turkey is the only country in the world that decreased both sheep and goat numbers (Dellal, 2001). Important reasons for decrease in goat numbers in Turkey are decrease in highland area used for goat grazing, expensive roughage sources, fluctuations in milk and meat price due to the lack of agricultural policies, problems in obtaining high quality breeding stock and not having done the sustainability analyses of goat enterprises and taking preventive measures accordingly.

\section{GOAT HUSBANDRY IN THE MEDITERRANEAN REGION OF TURKEY}

Of the goats in Turkey, $90.5 \%$ is composed of Hair goat and their milk and meat yield are well below of dairy goat breeds. With a $28 \%$ share in total number of goats in Turkey, the Mediterranean region is an important region for the goat production in Turkey. Isparta province has 168000 goats and is considered an important province for goat husbandry. Considering the fact that goat husbandry in Turkey is practiced in the mountainous area and vicinity of forests, geography, flora, pastures, the forest type, the climate conditions of Isparta make it a suitable place for goat husbandry.

Out the products obtained from goats in the Mediterranean region of Turkey, Isparta province produces 22, 40 and $40 \%$ of milk, meat, and skin, respectively (TUIK, 2005).

\section{ISPARTA PROVINCE AND ITS AGRICULTURAL STRUCTURE}

Isparta has mountainous topography with small hills and it also has considerable numbers of lakes and various sizes planes. Out the area of Isparta, 251252 ha are used for cultivation. In Isparta there are 325000 small ruminants of which 168000 are Hair goat and 157000 are sheep. Animal agriculture is an important branch of agriculture in Isparta and it provides a significant income source for people. There is a decline in the number of sheep, goat and cattle in Isparta. The reasons for decline in these numbers are high prices of inputs, low yields of native breeds and thus receiving low return for products.

\section{GOAT HUSBANDRY STRUCTURE OF ISPARTA}

The structural and socio-economic information of the Isparta goat husbandry is not well defined and not known. Thus preliminary structural information obtained from goat husbandry enterprises that are members of the Isparta goat and sheep breeders association will be used in this paper to describe the general structure of goat husbandry in Isparta. There are 168000 goats in Isparta and nearly all of them are Hair goat (TUIK, 2008).

\section{Table 1}

According to 2007 data on the milked, the slaugtered, the shorn and the skin obtained in Isparta (TUIK, 2008)

\begin{tabular}{lcccc}
\hline \hline & $\begin{array}{c}\text { Milked goat } \\
\text { (head) }\end{array}$ & $\begin{array}{c}\text { Slaughtered goat } \\
\text { (head) }\end{array}$ & $\begin{array}{c}\text { Skin } \\
\text { (number) }\end{array}$ & $\begin{array}{c}\text { Shorn goat } \\
\text { (head) }\end{array}$ \\
\hline Mature & 109689 & 13641 & 13700 & - \\
Kid & 58464 & 1668 & 1835 & - \\
\hline Total & 168153 & 15309 & 15534 & 109689 \\
\hline \hline
\end{tabular}

The amounts of meat, milk and hair obtained in 2004, 2005 and 2006 in Isparta are provided in Table 2.

Table 2

Amount of meat, milk, hair and skin obtained in 2004, 2005 and 2006 years in Isparta (TUIK, 2008)

\begin{tabular}{lccc}
\hline \hline & $\mathbf{2 0 0 4}$ & $\mathbf{2 0 0 5}$ & $\mathbf{2 0 0 6}$ \\
\hline Meat (ton) & 264 & 258 & 267 \\
Milk (ton) & 5906 & 5677 & 5608 \\
Hair (ton) & 61 & 56 & 60 \\
Skin (ton) & 12760 & 13667 & 15534 \\
\hline \hline
\end{tabular}

Since Isparta is mountainous and hilly, most of goat production is practiced in highlands. However in some villages people mix their goats form- 
ing a flock and a hired man grazes the goats. In this case goats are grazed around the village and every night the flock goes back to village for milking and staying. Contrary to other regions nomadic goat husbandry is not practiced in Isparta. Goat producers are involved in goat husbandry due to economical reasons (not having any other profession that helps them make living), or their cultural heritage or generating income. Goat producers utilize pastures under forests, shrubs in close vicinity of villages as roughage sources. Bucks are kept in flocks all around the year and does are impregnated by random. The biggest problem producers in mountainous and forest areas face are not being able to find good quality roughage and concentrate feeds during the lactation season. Considering that tradition and consumer behavior are a driving force behind any production design in a region, it could be said that goat husbandry in Isparta is mainly practiced for meat production. Goat meat is preferred due to cultural heritage and traditions in the region known as "Teke" where Isparta is located. Most of the goat meat is consumed as kids meat. Milk produced from goat is generally mixed with other milk and is used for cheese, ice cream and butter production. Most of the milk products are consumed in the household and the excess is sold in markets in towns. Even though goat milk is in high demand these days goat producers do not get the worth of their milk due to the lack of organizations that collect and process goat milk.

\section{SUSTAINABLE GOAT HUSBANDRY SUGGESTIONS FOR ISPARTA PROVINCE}

Sustainable agriculture, defined as the management and conservation of the resource base and the orientation of technological and institutional changes in such a manner as to ensure the attainment and continued satisfaction of human needs for present and future generations (FAO, 1991), has been a subject of great interest and ongoing debate in animal agriculture (Heitschmidt et al., 1996). Sustainable agriculture is a system that does not pollute soil and water sources with pollutants, minimizes energy use, protects animal species and environment and use organic substances to make production (Ocak, et al. 2005). Sustainability is considered in terms of energy use, economics and ecology. Thus sustainable systems should conserve energy, increase profit and should not have detri- mental effects on environment. Sustainability has gained a great importance due to increase in population and energy demand. The world population is increasing at an annual growth rate of $1.3 \%$ whereas energy use is projected to increase at an annual rate of $2.2 \%$ at the period from 1995 to 2015 (PRB, 2004; International Energy Annual, 1995). Therefore, as the world population and energy use increase, animal agriculture operations that are more sustainable, consume less energy and use less cereal grains.

Feed production in modern agriculture requires the input of high amounts of fossil energy (Tamminga, 1996). A curvilinear relation seems to exist between net energy content of the feed and the input of fossil energy and feeds are grouped as low, medium, and high energy input feeds (Tammimga, 1996) with the low energy input group being roughages. In the developed world, about 65 percent of the total agricultural land area is allocated to the production of cereals for livestock feed (FAO, 1995). Since grains constitute one sixth of the energy required by livestock ruminant production systems nutritional regimens should be manipulated to conserve fossil energy by inclusion of roughages that require low fossil energy input (Oltjen and Beckett, 1996; Koknaroglu et al., 2007a). As ruminants, goats have unique ability to use pastures, rangeland, and crop residues or other by-products and convert them into food. Thus this ability makes it easier to feed goats.

Energy output/cultural energy input ratio is of considerable value because it provides an estimate of our level of dependence on exogenous energy sources to meet established production goals (Heitschmidt et al., 1996). Furthermore, this ratio is one of the most useful methods to examine the potential long term sustainability of various agricultural practices and this analysis is performed to quantify the energy return from products relative to the cultural energy invested in the product (Heitschmidt et al., 1996).

Research showed that inclusion of pastures into animal production decreased dependency on grains and at the same time improved sustainability of production system by decreasing cultural energy input per energy output (Koknaroglu et al., 2007a; Koknaroglu et al., 2007b; Koknaroglu and Hoffman, 2002). In a study comparing the effect of the concentrate level on sustainability of beef cattle production, Koknaroglu (2008) found that the cultural energy expended for Mcal of protein en- 
ergy output decreased as the concentrate level increased, but this was not in a linear fashion, and at certain point, it started increasing as the concentrate level increased. Energy output/cultural energy input ratio of cattle receiving the intermediate level of concentrate was higher, implying that increasing the concentrate level does not necessarily mean better efficiency. The research conducted to compare sustainability of animal production systems showed that feed was the main contributor to the cultural energy input thus the feeding system that decreases cultural energy input of feed without interfering animal performance should be sought (Demircan, 2008; Koknaroglu, 2008; Demircan and Koknaroglu, 2007; Koknaroglu et al., 2007a; Koknaroglu et al., 2007b; Koknaroglu et al. 2006).

In the Isparta region goats are grazed on shrubs and pastures under forests nearly all the year around. Thus their cultural energy input expended on feed is minimal and this puts goats in a very special place as they convert shrubs that are not used by other farm animals into meat and fiber. In a survey study conducted in the region Demircan et al. (unpublished data) found that goat producers graze their goats around 11 months and they provide concentrate feed only during early lactation. Considering the less dependency of goats on external feed sources and feed as the main contributor of the cultural energy input into production systems it could easily be said that goat production would be sustainable in terms of energy output/cultural energy input ratio.

Hair goats are known for their disease resistance, adaptation to harsh environments and malnutrition. Hair goats in the region are not selected for production traits and they generally have low yields of milk and meat. The research conducted on the Hair goat showed that Hair goats do not have potential to apply selection on them (Güney, et al. 2005). Thus a better approach to improve their genetic potential is to crossbreed them with dairy goats (Güney et al. 2005). Dairy goats are recognized for their high milk yield and twinning. Thus crossbreeding Hair goats with dairy goats would increase milk yield, twinning and thus sustainability. The research conducted on the Hair goat showed that Hair goats had $71 \mathrm{~kg}$ milk yield whereas Saanen goats had 357.9-691.4 kg milk yield per lactation during a 222-247-day lactation length (Güney, et al. 1990; Sönmez and Şengonca 1964). $F_{1}$ crosses of Saanen $\times$ Hair goats had 1.41-
1.71 kids per birth, 316-404 $\mathrm{kg}$ of mik yield per lactation during a 187-298-day lactation length (Şengonca et al., 1970). These results showed that crossbreeding Hair goats in the region with dairy goats would increase yield and thus sustainability.

Another method to examine the potential long term sustainability of the production system is profitability or economics of the system. Economics is the driving force behind continuity of a production system, as a system that does not generate enough profit cannot be sustained and passed for the next generation. In a study conducted on goat producers in the Mediterranean region of Turkey, Dellal and Dellal (2005) found that income generated from goat husbandry constituted the major proportion of gross product value $(65.20 \%)$. In the same research Dellal and Dellal (2005) found that the gross profit per enterprise and per person were 8066 and $1280 \$$, respectively. Of this gross profit per enterprise and per person 5259 and $835 \$$ were obtained from the goat production. The same study revealed that $73.04 \%$ of the goat producers were situated near forests and shrub land (Dellal and Dellal, 2005). Since the goat producers were located around forests and shrub land, if they are not allowed to graze their goats under forests and driven off the area, their income would significantly decrease. In order to establish and renovate forests, and take preventive measures against erosions the Ministry of Forestry in Turkey closed 2.3 million hectares of area for grazing. Considering the dry mass would be obtained from this area, this area would support nutritional need of 1.6 million goats (Babayiğit and Keskin, 2005). This shows that preventive measures taken by the Ministry of Forestry are placing goat producers under stressful conditions. The Ministry of Forestry projected to decrease the number of Hair goats from 13.1 million in 1984 to 7.7 million in 1999 (Babayiğit and Keskin, 2005). However this decline in goat population is not considered low enough and the Ministry is planning to decrease this number to 1 million in the future. Dellal and Dellal (2005) stated that if goat producers in the Mediterranean region are forced to quit goat production their gross income would decrease 56.21 percent. This shows that goat production in the region is an important means of generating income. With a decline in numbers in goats some measures should be taken to increase income of goat producers. One way to increase income of goat producers is to increase yield of goats and thus obtain higher income per goat. For this purpose as it is aforementioned 
crossbreeding with dairy goats should be conducted. With the crossbreeding, crossbreds would have higher milk yield and twinning thus they would generate more income (Güney et al. 2005; Kaymakçı and Taşkın, 1997). Since crossbreds are calmer than Hair goats they would damage forests to a lesser extent (Güney et al., 2005). Another way to increase income of goat producers is to increase price received for their products. In goat producing enterprises in the Mediterranean region goat milk has great importance. Milk produced from goat is generally mixed with other milk (cow) and it is used for cheese, ice cream and butter production. Goat milk is as rich as cow milk in terms of nutrients and on a species basis it has higher dry matter and fat. Since fat globules in goat milk are smaller in diameter they are easier to be digested and this makes goat milk special (Uysal and Kilıç, 2005). Goat milk is also rich in short chain fatty acids that give aroma to the cheese and are easier to digest. In addition goat milk is rich in fatty acids such as caproic, caprilic, capric acids that are defending the body against foreign organisms and have antituberculosis effect (Adam, 1972; Maree, 1978). Considering all these beneficial effects of goat milk, organizations that collect and store goat milk in hygienic tanks should be established. The reason for goat producers not to receive enough money for their milk is that these producers are far from milk collection centers and cannot transport the milk to these centers. In 2004 around 17.5 million tourists visited Turkey and especially goat cheese consumed by tourists is imported from other countries and thus millions of dollars are spent. In order to decrease this expenditure organizations mentioned above could be functional and they would both increase income of goat farmers by paying worth of goat milk and at the same time save dollars being sent to other countries. Meat is also another important product obtained from goat production. Goats are generally grazed and they do not require much concentrated feeds however for fattening kids good quality roughages and concentrate are needed. For decreasing the price of concentrate and roughages goat producers should establish organizations and also some subsidies should be given to goat producers. Dellal and Dellal (2005) reported that hair obtained from goats are used for domestic use and did not have any commercial value. Thus in order to increase the income from hair a new research should be conducted on how to increase use of goat hair in other products. Special organizations marketing tradi- tional hand woven products in cities and touristic places should be established (Dellal and Dellal, 2005).

Defining sustainability is an important methodological approach in organic animal production (Ronchi and Nardone, 2003). In organic animal production environmentally friendly methods are used and chemical fertilizers, hormones, antibiotics, pesticides or gene manipulations are not used. Considering the structure of the goat producers in the Isparta region it can easily be said that most of the products produced are organic. Organic agriculture is designed according to the market needs and it has to meet some criteria. Since these criteria are observed generally yield is lower and the product produced is sold for a higher price. However this is not the case with the goat producers in Isparta and in order to be able to sell organic goat milk and meat some organizations should be established.

Researches have shown that the farm size increases the income of farmers and as the farm size increases profitability increases (Demircan et al., 2006; Demircan et al., 2007). Since the farm size increases the fixed cost decreases and this increases profitability of enterprises. In a survey study conducted in the region Demircan et al. (unpublished data) found that as the number of goats per farm increased profitability increased and the underlying reason for this outcome was labor used efficiently by larger farms. Thus the increasing number of goats in farms would increase profitability and thus sustainability.

\section{REFERENCES}

[1] Adam, R. C. (1972):. Keçi sütü. Yardımcı ders kitabı. Ege Üniversitesi Ziraat Fakültesi Yayın no:179, Ege Üniversitesi Matbaas1, İzmir.

[2] Babayiğit, İ., M. Keskin (2005): Keçi orman ilişkleri ve geleceği. Ege Üniversitesi Ziraat Fakültesi Zootekni Bölümü Bornova İzmir. pp 49-51.

[3] Dellal (2001): Akdeniz bölgesinde koyun ve keçi yetiştiriciliğinin ekonomik önemi. Isparta Yöresi Keçi ve Koyun Yetiştiriciliği Paneli. Süleyman Demirel Üniversitesi Ziraat Fakültesi Zootekni Bölümü. pp 37-45. Isparta.

[4] Dellal, I,, G. Dellal (2005): Türkiye keçi yetiştiriciliğinin ekonomisi. Süt keçiciliği ulusal kongresi. Ege Üniversitesi Ziraat Fakültesi Zootekni Bölümü Bornova İzmir. pp 39-48.

[5] Demircan, V., H. Koknaroglu, H. Yilmaz and Z. Dernek (2007): Economic analysis of beef cattle farms in Turkey. Journal of Applied Animal Research. 31:143-148. 
[6] Demircan, V., T. Binici, H. Koknaroglu and A. R. Aktas (2006): Economic analyses of different dairy farm sizes in Burdur province in Turkey. Czech Journal of Animal Science. 51 (1): 8-17.

[7] Demircan, V. (2008): The effect of initial fattening weight on sustainability of beef cattle production in feedlots. Spanish Journal of Agricultural Research, 6 (1): 17-24.

[8] Demircan, V., H. Koknaroglu (2007): Effect of Farm Size on Sustainability of Beef Cattle Production. Journal of Sustainable Agriculture, 31 (1): 75-87.

[9] FAO (1991): Sustainable agriculture and rural development in Asia and Pacific. The Netherlands: Regional Document No. 2. FAO/ Netherlands Conf. Agric. Envir.

[10] FAO (1995): World Agriculture: Towards 2010; An FAO study, Edited by Nikos Alexandratos, Food and Agriculture Organization of the United Nations, and John Wiley \& Sons, Chichester, England. pp. 434-435.

[11] Güney, O., L. Özcan, E. Pekel, O. Biçer, O. Torun, C. Gail, G. Nitter (1990): Çukurova-Hohenheim üniversiteleri bilimsel işbirliği III. Kollokyumu, 26-27 Kasım, Adana.

[12] Güney, O., M. Kaymakçı, O. Karaca, T. Savaş: Türkiye'de süt keçisi ıslahının geleceği üzerine kimi önreiler. Süt keçiciliği ulusal kongresi. Ege Üniversitesi Ziraat Fakültesi Zootekni Bölümü Bornova İzmir. pp 20 25.

[13] Heitschmidt, R. K., R. E. Short, and E. E. Grings (1996): Ecosystems, Sustainability, and Animal Agriculture. $J$. Anim. Sci. 74: 1395-1405.

[14] International Energy Annual (1995): DOE/EIA-0219[95]. U.S. Department of Energy, Washington, DC.

[15] Kaymakçı, M., T. Taşkın (1997): Goat improvement studies in arranging forest Hair goat relation in Turkey. Proceeding of the XI. World Forestry Congress. 13-22 October. Antalya, Volume 3.

[16] Koknaroglu H., M. P. Hoffman (2002): Integration of pasturing systems for cattle finishing programs. 2002 Beef Research Report, A.S. Leaflet R1779. Iowa State University.

[17] Koknaroglu, H. (2008): Effect of concentrate level on sustainability of beef cattle production. Journal of Sustainable Agriculture. 32 (1): 123-136.

[18] Koknaroglu, H., A. Ali, D. G. Morrical, M. P. Hoffman (2006): Breeding for sustainability: Effect of breed on cultural energy expenditure of lamb production. Czech Journal of Animal Science. 51 (9): 391-399.

[19] Koknaroglu, H., K. Ekinci, M. P. Hoffman (2007a): Cultural Energy Analysis of Pasturing Systems for Cattle Finishing Programs. Journal of Sustainable Agriculture 30 (1):5-20.

[20] Koknaroglu, H., A. Ali, K. Ekinci, D. G. Morrical and M. P. Hoffman (2007b):. Cultural Energy Analysis of Lamb Production in the Feedlot or on Pasture and in the Feedlot. Journal of Sustainable Agriculture. 30 (4):95-108.

[21] Maree, H. P. (1978) Goat milk and its use as hypoallergenic infant food. Dairy Goat Journal.

[22] Ocak, S., N. Darcan, O. Güney (2005): Sürüdürülebilir tarım içerisinde keçi yetiştiriciliği. Süt keçiciliği ulusal kongresi. Ege Üniversitesi Ziraat Fakültesi Zootekni Bölümü Bornova İzmir. pp 52-58.

[23] Oltjen, R. R., and J. L. Becket (1996): Role of ruminant livestock in sustainable agricultural systems. J. Anim. Sci. 74: 1406-1409.

[24] PRB (2004): World population data sheet. Washington, DC: Population Reference Bureau

[25] Ronchi, B., Nardone, A. (2003): Contribution of organic farming to increase sustainability of Mediterranean small ruminants livestock system. Livest. Prod. Sci. 80: 17-31.

[26] Şengonca, M., R. Sönmez, A. G. Alpbaz (1970): Ege Üniversitesi Ziraat Fakültesi'nde yetiştirilen Saanen $\times$ kıl ve Malta x kıl birinci generasyon melezlerinin çeşitli özellikleri ve verimleri üzerine mukayeseli bir araştırma. EÜZF Dergisi, cilt 11, sayı 3, İzmir.

[27] Sönmez, R., M. Şengonca (1964): Saanen süt keçilerinin Ege bölgesi şartlarına adaptasyonu ve verimleri üzerine araştırma. Ë̈ZF Dergisi, cilt 1, say1 2, İzmir.

[28] Tamminga, S. (1996): A review on environmental impacts of nutritional strategies in ruminants. J. Anim. Sci. 74: $3112-3124$.

[29] TUIK (2005): Turkish Statistical Institute.

[30] TUIK (2008): Turkish Statistical Institute.

[31] Uysal H., S. Kılıç (2005): Türkiye'de keçi sütü üretimi ve değerledirme olanakları. Süt keçiciliği ulusal kongresi. Ege Üniversitesi Ziraat Fakültesi Zootekni Bölümü Bornova İzmir. pp 36-38. 